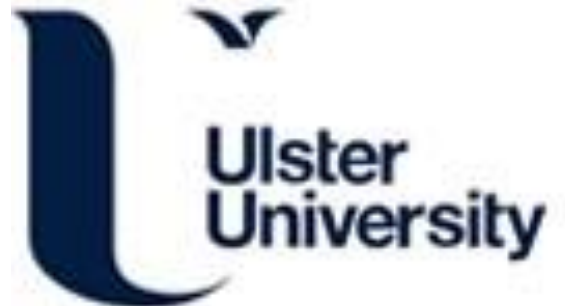

\section{Vitamin D3 content of cows' milk produced in Northern Ireland and its efficacy as a vehicle for vitamin D fortification: a UK model}

Weir, R., Johnston, M., Lowis, C., Fearon, A. M., Stewart, S., Strain, S., \& Pourshahidi, L. K. (2020). Vitamin D3 content of cows' milk produced in Northern Ireland and its efficacy as a vehicle for vitamin D fortification: a UK model. International Journal of Food Sciences and Nutrition. https://doi.org/10.1080/09637486.2020.1837743

Link to publication record in Ulster University Research Portal

\section{Published in:}

International Journal of Food Sciences and Nutrition

Publication Status:

Published online: $26 / 10 / 2020$

DOI:

10.1080/09637486.2020.1837743

\section{Document Version}

Author Accepted version

\section{General rights}

Copyright for the publications made accessible via Ulster University's Research Portal is retained by the author(s) and / or other copyright owners and it is a condition of accessing these publications that users recognise and abide by the legal requirements associated with these rights.

\section{Take down policy}

The Research Portal is Ulster University's institutional repository that provides access to Ulster's research outputs. Every effort has been made to ensure that content in the Research Portal does not infringe any person's rights, or applicable UK laws. If you discover content in the Research Portal that you believe breaches copyright or violates any law, please contact pure-support@ulster.ac.uk. 
1 Vitamin $D_{3}$ content of cows' milk produced in Northern Ireland and its efficacy as a vehicle for vitamin D fortification: a UK model

Ruth R. Weir ${ }^{1}$, Mike Johnston ${ }^{2}$, Carole Lowis ${ }^{2}$, Ann M. Fearon ${ }^{3}$, Sharon Stewart ${ }^{3}$, J.J. Strain ${ }^{1}$ and L. Kirsty Pourshahidi*1

${ }^{1}$ Nutrition Innovation Centre for Food and Health (NICHE), Ulster University, Coleraine, BT52 1SA, UK

${ }^{2}$ Dairy Council for Northern Ireland (DCNI), Shaftesbury House, Edgewater Road, Belfast, BT3 9JQ, UK

${ }^{3}$ Agri-Food and Biosciences Institute (AFBI), Newforge Lane, Belfast, BT9 5PX, UK

\section{Authors' names for indexing:}

Weir RR, Johnston M, Lowis C, Fearon AM, Stewart S, Strain JJ, Pourshahidi LK

\section{Author emails, ORCiDs and social media:}

R.R. Weir (rrweir89@gmail.com, LinkedIn: ruth-weir-39272689/)

M. Johnston (mike.johnston@dairycouncil.co.uk, Twitter: @DairyCouncilNI, LinkedIn: drmike-johnston-439a471b/)

C. Lowis (carole@,foodcommunications.co.uk, Twitter: @DairyCouncilNI, LinkedIn: carolelowis-7381859b/)
A.M. Fearon (annmoruzzi@btopenworld.com, Twitter: @,AFBI_NI)

S. Stewart (haron.stewart@,afbini.gov.uk, Twitter: @,AFBI_NI)

J.J. Strain (ij.strain@ulster.ac.uk, ORCiD: 0000-0002-1633-2873, Twitter:

@NICHE_ULSTER, LinkedIn: sean-strain-67505617/)

L.K. Pourshahidi (k.pourshahidi@ulster.ac.uk,ORCiD: 0000-0003-2251-5251, Twitter:

@DrKirstyP, LinkedIn: kirsty-pourshahidi)

\section{*Corresponding author:}

Dr Kirsty Pourshahidi, Nutrition Innovation Centre for Food and Health (NICHE), School of Biomedical Sciences, Ulster University, Coleraine, BT52 1SA, UK.

Tel: +44 (0) 287012 4030; Email: k.pourshahidi@ulster.ac.uk 
35

36

37

\section{Abstract}

Cows' milk is a relatively poor source of vitamin D but figures listed in UK food composition tables may be outdated. Samples of milk were collected for 1-year and vitamin $\mathrm{D}_{3}$ concentrations analysed using HPLC. Milk consumption data were obtained from the National Diet and Nutrition Survey (Years 1-4). A theoretical model applied vitamin $\mathrm{D}_{3}$ fortifications of $1 \mu \mathrm{g}, 1.5 \mu \mathrm{g}$ and $2 \mu \mathrm{g} / 100 \mathrm{~g}$ to simulate improvements in vitamin $\mathrm{D}$ intakes. Mean $\pm \mathrm{SD}$ vitamin $\mathrm{D}_{3}$ in whole milk was $0.06 \pm 0.02 \mu \mathrm{g} / 100 \mathrm{~g}$. No seasonal differences were apparent. Fortification of cows' milks with $1 \mu \mathrm{g}, 1.5 \mu \mathrm{g}$ and $2.0 \mu \mathrm{g} / 100 \mathrm{~g}$, theoretically increased median vitamin D intakes from $2.0 \mu \mathrm{g} /$ day to $4.2 \mu \mathrm{g}, 5.1 \mu \mathrm{g}$ and $5.9 \mu \mathrm{g} /$ day, respectively. Higher vitamin $\mathrm{D}_{3}$ in milk from this study than that currently in food composition tables, suggests further analysis is warranted. This model suggests vitamin D fortification of cows' milk is an effective strategy to help more of the population achieve recently revised RNIs for vitamin D.

Keywords: Vitamin D; fortification; cows milk; food composition; dietary intake; model; NDNS 


\section{Introduction}

Vitamin D plays an essential role in the metabolism of calcium by increasing its absorption in the small intestine (COMA 1991) and for this reason vitamin D has an important role to play in musculoskeletal health (Lanham-New 2008; Pojednic \& Ceglia 2014; Todd et al. 2015). Vitamin D deficiency has been known for many years to be a factor in sub-optimal bone health and to lower bone mineral density (Thacher \& Clarke 2011). Moreover, poor vitamin D status has been more recently associated with many other non-skeletal chronic conditions such as cardiovascular disease, certain cancers, decline in cognitive function, type II diabetes, and rheumatoid arthritis (Martini \& Wood 2009; Kostoglou-Athanassiou et al. 2012; Autier et al. 2014; Feldman et al. 2014). Vitamin D insufficiency (25-hydroxyvitamin D [25(OH)D] concentration of $<50 \mathrm{nmol} / 1)$ and deficiency $(25(\mathrm{OH}) \mathrm{D}$ concentrations of $<25 \mathrm{nmol} / \mathrm{l})$ (IOM 2011) are prevalent, with an estimation that 1 billion people could be classed as insufficient or deficient worldwide (Holick 2007). The Irish Adult Nutrition Survey (NANS), reported that approximately one third of adults aged 18-84 y were classed as vitamin D insufficient during the summer, while in the winter this increased to over half of the adult population (IUNA 2011; Cashman et al. 2013). Similar findings regarding vitamin D insufficiency have been noted in the UK National Diet and Nutrition Survey (Public Health England 2014).

The majority of vitamin D required by humans is derived by ultraviolet (UV)-B radiation of the 7-dehydrocholesterol in the skin (COMA 1991; Webb \& Holick 1988), although a number of factors negatively influence the skin's ability to synthesise the vitamin (Hagenau et al. 2009). Such factors include increasing age, skin pigmentation, clothing, sedentary/indoor lifestyles, the use of sun protection and geographical location (i.e. latitude). It has been long established that the northerly latitude of the UK and Ireland [50$60^{\circ} \mathrm{N}$ ] means UVB intensity is inadequate to promote the dermal synthesis of vitamin D during the winter months (approximately October-March) (Webb et al. 1998; Hill et al. 2008), causing the population to be solely reliant on dietary sources during this time to maintain the body's stores of the vitamin. Despite this reliance on dietary sources, previous literature from the UK and Ireland more often than not report low intakes of vitamin D $(<5 \mu \mathrm{g} / \mathrm{d})$, because naturally occurring food sources are so limited (IUNA 2011; Public Health England 2014). More worryingly, these figures are considerably lower than the revised reference nutrient intake (RNI) suggested by the Scientific Advisory Committee on Nutrition $(\mathrm{SACN})$ of $10 \mu \mathrm{g} / \mathrm{d}$ of vitamin D daily for the general population aged $4+\mathrm{y}$ (or the safe intake $10 \mu \mathrm{g} / \mathrm{d}$ for children aged 1-4 y) (SACN 2016). 
Fortified foods are increasingly contributing to the dietary intake of the population, especially in those who do not also consume dietary supplements (Black et al. 2012). Although milk and dairy products are sources of naturally occurring vitamin D (McCance \& Widdowson 2002; BDA 2007), without fortification, the vitamin D content of milk is minimal and has also been known to vary considerably from winter to summer (Kurmann \& Indyk 1994; Jakobsen \& Saxholt 2009). 'The Composition of Foods' series by McCance and Widdowson (2014) provides extensive nutritional data on a number of foods. Although these tables have been updated several times since their inception, the most recent $7^{\text {th }}$ edition (published in 2014), has reported the lowest vitamin D content for whole, semi-skimmed and skimmed milk (i.e. as trace) compared to earlier editions, based on limited sampling.

One possible strategy to increase vitamin D intakes within the population is through the fortification of milk, which is a staple dietary component for a large proportion of the UK and Irish population. In Canada, the fortification of liquid milk is mandatory at concentrations ranging from $0.875 \mu \mathrm{g}-1.125 \mu \mathrm{g} / 100 \mathrm{ml}$ (IOM 2011). Indeed, numerous studies have reported the effectiveness of dairy fortification in increasing vitamin D intake in other countries (Calvo et al. 2004; Harika et al. 2016; Jaaskelainen et al. 2017). Within the UK, however, mandatory fortification with vitamin D is limited to a few foods only, including margarine, energyrestricted foods for diets intended for weight loss and infant formula (Hypponen \& Power 2007; Allen 2015). Vitamin D is only added to a small number of other foods at the discretion of the food industry (e.g. yogurts, cereals and breads).

Owing to the low dietary intakes previously reported, and the relatively low uptake of food fortification in the UK/Ireland, alternative food-based strategies to improve consumers' vitamin D intakes, and status are warranted. Therefore, the aims of the current study are to, (1) determine the concentrations of vitamin $\mathrm{D}_{3}$ in cows' milk produced in Northern Ireland (NI), and; (2) simulate how fortification of cows' milk could theoretically improve overall dietary vitamin $\mathrm{D}$ intakes of the UK population using a dietary modelling scenario.

\section{Materials and methods}

\section{Study samples}

The sampling protocol was designed to be representative of cows' milk on retail sale in NI. Monthly 1L samples of raw and whole pasteurised milk (standardised to a minimum fat content of 3.5\%) were collected for a period of 1 year (May 2013 - May 2014) from two dairy processors. All milk samples were collected by staff based within the processing 
plants. Raw milk samples were collected immediately pre-pasteurisation. Owing to the well documented seasonal variation in vitamin D content, milk samples collected during OctoberMarch are referred to as winter milk, while those samples collected between April and September are referred to as summer milk hereafter. Samples were stored at $-20^{\circ} \mathrm{C}$ prior to analysis. Quantification of vitamin $\mathrm{D}_{3}$ content in stored samples were analysed by HPLC (Agilent 1200 Series) (method adapted from Trenerry et al. (2011). Samples were run with a $99 \%$ acetonitrile: $1 \%$ methanol mix at a rate of $1.5 \mathrm{ml}$ per min for $50 \mathrm{mins}$. Vitamin $\mathrm{D}_{3}$ was quantified at the 265/280 wavelengths.

\section{Population dietary data}

The NDNS Rolling Programme Years 1-4 (2008/09-2011/12) dataset was used to provide nationally representative data on both current vitamin $\mathrm{D}$ intakes $(\mu \mathrm{g} / \mathrm{d})$ and typical milk consumption (g) of the UK population (UK Data Service 2014). The dataset comprises of 3 or 4-d food diaries from 4,156 individuals [2,174 adults (18-94 y) and 1,982 children (1.5$17 \mathrm{y})$ ]. Consumption of whole, semi-skimmed, skimmed and $1 \%$ milks were included in the current analysis. The theoretical impact of vitamin D fortification was evaluated for the entire study population and by age group [children (1.5-17 y old and adults ( $\geq 18$ years)]. Attention was also given to sub-groups considered to be at-risk of vitamin D deficiency: young children (aged 1.5-3 y); adults over the age of 65 y (COMA 1991); women of childbearing age (16-49 y) (Public Health England 2014).

\section{Dietary modelling}

The vitamin D content of milk as listed in the McCance and Widdowson (2002) was used in the most recent NDNS analysis and therefore acted as the baseline for the current dietary model. Vitamin D fortification concentrations of $1 \mu \mathrm{g} / 100 \mathrm{~g}, 1.5 \mu \mathrm{g} / 100 \mathrm{~g}$ and $2 \mu \mathrm{g} / 100 \mathrm{~g}$ were selected based on the American and Canadian fortification levels and those of enriched 'super-milks' which are commercially available in the UK and Ireland. These fortification concentrations were then applied to the consumption of whole, semiskimmed, skimmed and $1 \%$ milk to estimate the effect fortification at these concentrations would have on the overall vitamin D intakes of the population. As part of this dietary model, the current tolerable upper limits (UL) for daily vitamin D intake were considered to determine if the fortification scenario would subsequently give rise to consumer intakes exceeding the UL. The ULs used were those provided by European Food Safety Authority 
(EFSA) at $100 \mu \mathrm{g} / \mathrm{d}$ for individuals aged $11+\mathrm{y}, 50 \mu \mathrm{g}$ for children between 1 and $10 \mathrm{y}$, and $25 \mu \mathrm{g}$ for infants $<1 \mathrm{y}($ EFSA 2012).

\section{Statistical analysis}

The Statistical Package for the Social Sciences (IBM SPSS Statistics 22, Chicago, IL, USA) was used for analysis of all data. Values of $P<0.05$ were regarded as statistically significant throughout. Normality of the data was assessed using Kolmogorov-Smirnov tests, and where data could not be normalised, the results are expressed as medians (25th and 75th percentiles). Descriptive statistics and t-tests were used to describe the study sample and to compare the concentrations of vitamin D present within the different forms of milk between seasons (summer and winter) and between milk types (raw and pasteurised whole) and to compare intakes to the current reference nutrient intake (RNI) (SACN 2016) and tolerable UL (EFSA 2012). The comparison of vitamin D intakes at baseline and post-fortification were tested using non-parametric tests, Wilcoxon Signed Rank test.

\section{Results}

\section{Vitamin D analysis of milk}

The average year-round mean $\pm \mathrm{SD}$ vitamin $\mathrm{D}_{3}$ content of Northern Irish raw and pasteurised whole milk collected as part of this study was $0.08 \pm 0.04 \mu \mathrm{g} / 100 \mathrm{~g}$ and $0.06 \pm$ $0.02 \mu \mathrm{g} / 100 \mathrm{~g}$ respectively, with a range of $0.01-0.16 \mu \mathrm{g} / 100 \mathrm{~g}$ for raw milk (Figure 1 ) and $0.03-$ $0.12 \mu \mathrm{g} / 100 \mathrm{~g}$ for pasteurised whole milk (Figure 2 ). The mean $\pm \mathrm{SD}$ vitamin $\mathrm{D}_{3}$ content per $100 \mathrm{~g}$ between summer vs. winter milk was not significantly different for either raw $(0.07 \pm$ $0.03 \mu \mathrm{g}$ vs. $0.08 \pm 0.04 \mu \mathrm{g}$ per $100 \mathrm{~g} ; P=0.479)$ or pasteurised whole milk $(0.07 \pm 0.03 \mu \mathrm{g}$ vs. $0.05 \pm 0.01 \mu \mathrm{g}$ per $100 \mathrm{~g} ; P=0.227$ ). A significant difference was noted when comparing the vitamin $\mathrm{D}_{3}$ content of raw and pasteurised whole milk throughout the year $(P=0.037)$. When a seasonal comparison of the vitamin $\mathrm{D}_{3}$ content of raw and pasteurised whole milk was investigated, a significant difference was noted in winter $(P=0.033)$ but not in summer $(P=0.506)$.

\section{NDNS data}

A total of 16,539 recorded dietary days were available for analysis from the raw NDNS dataset [32] of which, 13,962 dietary days (84.4\%) reported an intake of milk. Survey 
population data can be found in Table 1. Daily milk intakes (portion size per eating occasion) ranged from $2.5 \mathrm{~g}$ to $2850 \mathrm{~g}$. On average, a larger portion size of whole milk was consumed compared to the other three milk types (Figure 3). Semi-skimmed milk was the most commonly consumed milk (Figure 4 ) in the total study population $(53.1 \%$ of dietary days). A higher proportion of children (aged 1.5 to $17 \mathrm{y}$ ) were consumers of whole milk compared to adults $(P<0.001)$, and the opposite was true for the other three milk types; however, significant difference was only seen in skimmed milk consumption $P<0.001$ (semiskimmed $P=0.509 ; 1 \%$ fat $P=0.505$ ) (Figure 4).

Mean dietary vitamin D intake at baseline for the entire study population was $2.50 \mu \mathrm{g} / \mathrm{day}$ (SD 1.87) with a range of $0.00-20.96 \mu \mathrm{g}$ (Table 2). Mean daily vitamin D intakes were significantly higher for males compared to females $(2.71 \pm 2.09 \mu \mathrm{g}$ vs. $2.31 \pm 1.65 \mu \mathrm{g}$; $P<0.001$ ). Adults also had a significantly higher daily vitamin $\mathrm{D}$ intake compared to children $(2.92 \pm 2.13 \mu \mathrm{g}$ vs. $2.04 \pm 1.42 \mu \mathrm{g} ; P<0.001)$. Baseline vitamin $\mathrm{D}$ intakes in at-risk groups are shown in Table 3 and also increased with age.

\section{Dietary modelling scenario}

Of the 4,156 individuals surveyed as part of the NDNS, only $37(0.89 \%)$ met the new RNI of $10 \mu \mathrm{g} / \mathrm{d}$, but following the fortification scenario applied in this dietary model these figures increased. When a fortification of $2 \mu \mathrm{g} / 100 \mathrm{~g}$ was applied $511(12.29 \%)$ of the study population achieved the new RNI (Table 2).

Prior to applying the fortification scenario, six women of childbearing age $(0.74 \%)$ met the RNI of $10 \mu \mathrm{g} / \mathrm{d}$ (SACN 2016), following theoretical fortification at $2 \mu \mathrm{g} / 100 \mathrm{~g}$ this figure increased to $41(5.04 \%)$ participants. The same increase was seen in those over $65 \mathrm{y}$, with a total number of individuals reporting an intake of $10 \mu \mathrm{g} / \mathrm{d}$ or above increasing from seven $(1.65 \%)$ to $76(17.76 \%)$. The greatest effect of fortification was seen in children (aged 1-3 y). At the highest fortification, 99 (25.65\%) children would be meeting their recommended intake, compared to baseline where only eight (2.12\%) were meeting recommended intakes. Up to the highest fortification $(2 \mu \mathrm{g} / 100 \mathrm{~g})$, no participants exceeded the age-specific tolerable UL (EFSA 2012), either in the total population (Table 2) or in at-risk groups (Table $3)$.

When looking at diary days, fortification was shown to increase the vitamin D intake of the entire population with median intakes increasing from $2.3 \mu \mathrm{g} / \mathrm{d}$ to $6.1 \mu \mathrm{g} / \mathrm{d}$ for semiskimmed milk. For whole milk a similar increase was seen, with a median intake of $1.8 \mu \mathrm{g} / \mathrm{d}$ 
at baseline and $7.4 \mu \mathrm{g} / \mathrm{d}$ following fortification at the highest concentration $(2 \mu \mathrm{g} / 100 \mathrm{~g})$. The effect of simulated fortification at each concentration is shown in Table 4, and fortification at all three concentrations $(1 \mu \mathrm{g}, 1.5 \mu \mathrm{g}$ and $2 \mu \mathrm{g}$ per $100 \mathrm{~g})$ resulted in significantly increased vitamin D intakes for all milk types $(P<0.001)$.

\section{Discussion}

Results from this study clearly demonstrate that a vitamin D fortification policy for milk could potentially help increase the percentage of the population $(>12 \%)$ achieving the revised $\mathrm{RNI} /$ safe intakes of $10 \mu \mathrm{g} /$ day vitamin D (SACN 2016). Moreover, even with the highest fortification scenario $(2 \mu \mathrm{g} / 100 \mathrm{~g})$, no participant within the current fortification model had a vitamin D intake that exceeded EFSA's tolerable UL $(100 \mu \mathrm{g} / \mathrm{d}$ for $11+\mathrm{y} ; 50 \mu \mathrm{g} / \mathrm{d}$ for $1-10 \mathrm{y})$ (EFSA 2012), suggesting that fortification of milk with vitamin D would be safe in this respect.

A RNI/safe intake of $10 \mu \mathrm{g} / \mathrm{d}$ was proposed to ensure that a year-round serum $25(\mathrm{OH}) \mathrm{D}$ concentration of $\geq 25 \mathrm{nmol} / 1$ is achieved by the $97.5 \%$ of the population (SACN 2016). In the current study, a large proportion of those individuals considered to be 'at-risk' (young children aged 1.5-3 y, women of childbearing age (16-49 y), and those aged $65+\mathrm{y})$ fell short of the RNI. Although the fortification model was able to successfully increase the proportion of individuals meeting the RNI, the problem was not completely eliminated. This finding emphasises the importance and need for further strategies to increase vitamin D awareness and intake among these groups, particularly in those who may avoid milk/dairy products as part of their habitual diets.

Dietary modelling results similar to those reported by the current study have previously been shown by some (Jayaratne et al. 2013; Harika et al. 2016; Ejtahed et al. 2016; Moyersoen et al. 2019) but not others (Allen et al. 2015). In an Iranian population, Ejtahed and colleagues (2016) reported an increase in vitamin D intakes from $2.5 \mu \mathrm{g}$ to $3.3 \mu \mathrm{g} / \mathrm{d}$ after simulated fortification of milk, which is in line with that reported in the current study for the same fortification $(1 \mu \mathrm{g} / 100 \mathrm{~g})$. Jayaratne et al. (2013) also reported a positive effect of a fortification model, with higher increases in intakes shown $(3.6 \mu \mathrm{g}$ to $6.3 \mu \mathrm{g} / \mathrm{d})$, albeit this was achieved by fortifying both milk and breakfast cereals so the bigger effect on daily intake is not unexpected.

In contrast, negative effects of a milk fortification model on vitamin D intakes were reported in another recent study using UK population dietary survey data. Allen and 
colleagues (2015) found that fortification at certain concentrations put a number of participants at risk of exceeding the tolerable UL which is at variance to the current study, even following the highest fortification scenario $(2 \mu \mathrm{g} / 100 \mathrm{~g})$. This study, however, used older NDNS results collected in fewer participants than used in the current study, and also failed to justify the considerably higher fortification concentrations chosen. Furthermore, the lower values quoted for the tolerable UL of vitamin D intakes were those of the older European Committee report (European Scientific Committee on Food 2002), as opposed to the more recent guidelines from EFSA (2012).

The fortification model used in the current study demonstrated an increased vitamin D intake for the entire population, with whole milk having the largest impact on vitamin D intake as a result of the larger portion size consumed per eating occasion. Despite this larger portion size, as semi-skimmed milk was the most frequently consumed milk in the population overall, its fortification would benefit a greater number of people and therefore have the greatest impact on the vitamin D intake at a population level.

The vitamin $\mathrm{D}_{3}$ concentrations in milk reported in this study are at variance with the results published in some of the latest editions of the McCance and Widdowson (2002; 2014). The $7^{\text {th }}$ edition (2014) lists vitamin D for all types of cows' milk as 'trace' with the exception of milk from the Channel Islands which is listed at $0.01 \mu \mathrm{g} / 100 \mathrm{~g}$ (McCance \& Widdowson 2014). The previous edition listed the average vitamin D content of whole, semi-skimmed and skimmed milk as $0.03 \mu \mathrm{g}, 0.01 \mu \mathrm{g}$ and trace per $100 \mathrm{~g}$, respectively (Holland et al. 1989; McCance \& Widdowson 2002). The increases in vitamin $\mathrm{D}_{3}$ content of raw and whole milk found in this study, may be as a result of improvements in laboratory methods (Weir et al. 2017). Earlier methods of laboratory analysis presented numerous methodological challenges owing to vitamin D's complex structure, often causing complications when extracting the vitamin from the food matrix (Byrdwell et al. 2008) which may also have contributed to the differences in vitamin $\mathrm{D}_{3}$ content reported. Seasonal variation in vitamin $\mathrm{D}$ content in milk across the world has been well documented in the literature (Kurmann \& Indyk 1994; Jakobsen \& Saxholt 2009) but is not supported by the current study and may be a result of poor weather patterns. In recent years the weather has become more over-cast during the summer months (Sweeney 2016), and this decreases the opportunity for dermal synthesis of vitamin $\mathrm{D}_{3}$ not only in humans, but also in cattle which synthesise the vitamin in a similar manner (Hymoller \& Jensen 2010). Subsequently, the vitamin D status of the cattle influences the vitamin D concentration of the milk produced (Hollis et al. 1981) and therefore, animal husbandry in future should be adapted to ensure a more consistent vitamin D supply 
throughout the year.

Whilst interpreting the current results, a number of limitations should be noted. First is the use of self-reported dietary intakes, as misreporting in the form of under- or over-reporting of certain foodstuffs is a commonplace in participants (Willet 2013). During the NDNS Rolling Programme, the doubly-labelled water technique was used to validate the reported energy intake (Public Health England 2014) and improves confidence in the data. Moreover, the use of dietary data from the largest nationally representative survey in the UK was the most appropriate to test our hypothesis and such data was considerably more reliable than that collected from smaller surveys. Current results are also strengthened by the successful vitamin d fortification programme in Finland (Raulio et al. 2017), and add to the rationale to incorporate fortification in a wide range of food types. Secondly, it was beyond the scope of this project to measure the vitamin $\mathrm{D}_{3}$ content of all milk types (e.g. semi-skimmed and skimmed), but up-to-date results for the vitamin $\mathrm{D}_{3}$ content of raw and whole milk from NI have been quantified using a more advanced laboratory technique. Although these values are specific to NI milk, this approach provides novel data on a specific region of the UK, rather than using values from a more widespread and varied pool of data. Owing to the higher vitamin $\mathrm{D}_{3}$ content of milk reported compared to that in the most recent UK Composition of Foods (McCance \& Widdowson 2014), a more widespread update of the vitamin D content of UK milk is warranted. It would also be advantageous to use an alternative analytical technique, such as liquid chromatography mass spectrometry (LC-MS) (Trenerry et al. 2011) in future studies. This more sensitive method would also enable the quantification of the concentrations of other vitamin $\mathrm{D}$ metabolites present within milk, e.g. vitamin $\mathrm{D}_{2}$ and $25(\mathrm{OH}) \mathrm{D}$, which contribute to the total vitamin D content (Cashman 2012). Finally, this study has highlighted the potential beneficial effect of fortifying cows' milk with vitamin D on vitamin D intakes across the UK population. Further analysis should determine how this approach would impact the vitamin D contribution from other dairy products (made from the fortified milk), as well as the vitamin D status of the consumer.

\section{Conclusion}

This study suggests that the fortification of UK cows' milk with vitamin D (up to a concentration of $2 \mu \mathrm{g} / 100 \mathrm{~g}$ ) could be an effective dietary strategy to increase consumer's vitamin D intake, helping more of the UK population to achieve the newly revised RNI for vitamin $\mathrm{D}$ of $10 \mu \mathrm{g} / \mathrm{d}$. Importantly, this strategy could translate into a beneficial effect on 
306 consumer's vitamin D status, without putting anyone at risk of exceeding the tolerable UL for 307 the vitamin. Based on the results from this dietary modelling scenario, fortification of all types 308 of milk (whole, semi-skimmed, skimmed and 1\% milks) is recommended to maximise the 309 impact to consumers of all ages and make progress towards eradicating vitamin D deficiency 310 among the UK population. 
311 Acknowledgements: The authors would like to acknowledge Alan Beattie for his 312 involvement in the study during his time at AFBI, Dr Maria O'Kane for her assistance with 313 milk collections, and the two milk processors who provided the milk samples in kind for 314 analysis in this study. The authors dedicate this article to the memory of their colleague 315 Professor Julie Wallace (April 7, 1971-February 7, 2012).

316 Financial Support: The work was supported by a Collaborative Award in Science \& 317 Technology (CAST) PhD studentship award funded by the Department of Employment and 318 Learning, and the Dairy Council for Northern Ireland (DCNI). Authors from DCNI 319 contributed to the study design, interpretation of findings and preparation of the manuscript.

320 Authorship: The author responsibilities were as follows: M.J., C.L., A.M.F., J.J.S. and L.K.P 321 designed the research. R.R.W. and S.S. conducted the research. R.R.W. analysed the data and prepared the manuscript. All authors were involved in interpreting the results, and all read and approved the final manuscript.

324 Disclosure statement: The authors declare no conflicts of interest 


\section{References}

Allen RE, Dangour AD, Tedstone AE, Chalabi Z. 2015. Does Fortification of Staple Foods Improve Vitamin D Intakes and Status of Groups at Risk of Deficiency? A United Kingdom Modeling Study. Am J Clin Nutr. 102: 338-344.

Autier P, Boniol M, Pizot C, Mullie P. 2014. Vitamin D Status and Ill Health: A Systematic Review. Lancet Diabetes Endocrinol. 2:76-89.

Black LJ, Seamans KM, Cashman KD, Kiely M. 2012. An Updated Systematic Review and MetaAnalysis of the Efficacy of Vitamin D Food Fortification. J Nutr. 142:1102-1108.

British Dietetic Association. Vitamins. 2007. In Manual of Dietetic Practice, 4th Edition ed. Thomas B and Bishop J, Eds. Blackwell Publishing: Kent, pp.189-191.

Byrdwell WC, Devries J, Exler J, Harnly JM, Holden JM, Holick MF, Hollis BW, Horst RL, Lada M, Lemar LE, Patterson KY, Philips KM, Tarrago-Trani MT, Wolf WR. 2008. Analyzing Vitamin D in Foods and Supplements: Methodologic Challenges. Am J Clin Nutr. 88:554S-557S.

Calvo MS, Whiting SJ, Barton CN. 2004. Vitamin D Fortification in the United States and Canada: Current Status and Data Needs. Am J Clin Nutr. 80:1710S-1716S.

Cashman KD. 2012. The role of vitamers and dietary-based metabolites of vitamin D in prevention of vitamin D deficiency. Food Nutr Res. 56:5383.

Cashman, K.D.; Muldowney, S.; McNulty, B.; Nugent, A.; FitzGerald, A.P.; Kiely, M.; Walton, J.; Gibney, M.J.; Flynn, A. (2013) Vitamin D Status of Irish Adults: Findings from the National Adult Nutrition Survey. Br J Nutr 109, 1248-1256.

Committee on Medical Aspects of Food Policy (COMA). 1991. Dietary Reference Values for Food and Energy and Nutrients for the United Kingdom, Report on Health and Social Subjects. No.41.

EFSA Panel on Dietetic Products, Nutrition and Allergies (NDA). 2012. Scientific Opinion on the Tolerable Upper Intake Level of Vitamin D. EFSA J. 2813.

Ejtahed HS, Shab-Bidar S, Hosseinpanah F, Mirmiran P, Azizi F. 2016. Estimation of Vitamin D Intake Based on a Scenario for Fortification of Dairy Products with Vitamin D in a Tehranian Population, Iran. J Am Coll Nutr. 35:383-391.

European Scientific Committee on Food. 2002. Opinion of the Scientific Committee on Food on the Tolerable Upper Intake Level of Vitamin D.

Feldman D, Krishnan AV, Swami S, Giovannucci E, Feldman BJ. 2014. The Role of Vitamin D in Reducing Cancer Risk and Progression. Nat Rev Cancer. 14:342-357.

Hagenau T, Vest R, Gissel TN, Poulsen CS, Erlandsen M, Mosekilde L, Vestergaard P. 2009. Global Vitamin D Levels in Relation to Age, Gender, Skin Pigmentation and Latitude: An Ecologic Meta-Regression Analysis. Osteoporos Int. 20:133-140.

Harika RK, Dotsch-Klerk M, Zock PL, Eilander A. 2016. Compliance with Dietary Guidelines and Increased Fortification can Double Vitamin D Intake: A Simulation Study. Ann Nutr Metab. 69:246-255. 
Hill TR, Cotter AA, Mitchell S, Boreham CA, Dubitzky W, Murray L, Strain JJ, Flynn A, Robson PJ, Wallace JM, Kiely M, Cashman KD. 2008. Vitamin D Status and its Determinants in Adolescents from the Northern Ireland Young Hearts 2000 Cohort. Br J Nutr. 99:1061-1067.

Holick MF. 2007. Vitamin D Deficiency. N Engl J Med. 357:266-281.

Holland B, Unwin ID, Buss DH. 1989. Milk Products and Eggs: The Fourth Supplement to McCance \& Widdowson's The Composition of Foods. Royal Society of Chemistry: Cambridge.

Hollis BW, Roos BA, Draper HH, Lambert PW. 1981. Vitamin D and its Metabolites in Human and Bovine Milk. J Nutr. 111:1240-1248.

Hymoller L, Jensen SK. 2010. Vitamin $\mathrm{D}_{3}$ Synthesis in the Entire Skin Surface of Dairy Cows Despite Hair Coverage. J Dairy Sci. 93:2025-2029.

Hypponen E, Power C. 2007. Hypovitaminosis D in British Adults at Age 45 Y: Nationwide Cohort Study of Dietary and Lifestyle Predictors. Am J Clin Nutr. 85:860-868.

Institute of Medicine (IOM). 2011. Dietary Reference Intakes for Calcium and Vitamin D.

Irish Universities Nutrition Alliance (IUNA). 2011. National Adult Nutrition Survey: Summary Report.

Jääskeläinen T, Itkonen ST, Lundqvist A, Erkkola M, Koskela T, Lakkala K, Dowling KG, Hull GL, Kröger H, Karppinen J, Kyllönen E, Härkänen T, Cashman KD, Männistö S, Lamberg-Allardt C. 2017. The Positive Impact of General Vitamin D Food Fortification Policy on Vitamin D Status in a Representative Adult Finnish Population: Evidence from an 11-Y Follow-Up Based on Standardized 25-Hydroxyvitamin D Data. Am J Clin Nutr. 105:1512-1520.

Jakobsen J, Saxholt E. 2009. Vitamin D Metabolites in Bovine Milk and Butter. J Food Comp Anal. 22:472-478.

Jayaratne N, Hughes MC, Ibiebele TI, van den Akker S, van der Pols JC. 2013. Vitamin D Intake in Australian Adults and the Modeled Effects of Milk and Breakfast Cereal Fortification. Nutrition. 29:1048-1053.

Kostoglou-Athanassiou I, Athanassiou P, Lyraki A, Raftakis I, Antoniadis C. 2012. Vitamin D and Rheumatoid Arthritis. Ther Adv Endocrinol Metab. 3:181-187.

Kurmann A, Indyk H. 1994. The Endogenous Vitamin D Content of Bovine Milk: Influence of Season. Food Chem. 50:75-81.

Lanham-New SA. 2008. Importance of Calcium, Vitamin D and Vitamin K for Osteoporosis Prevention and Treatment. Proc Nutr Soc. 67:163-176.

Martini LA, Wood RJ. 2009. Milk Intake and the Risk of Type 2 Diabetes Mellitus, Hypertension and Prostate Cancer. Arq Bras Endocrinol Metabol. 53:688-694.

McCance RA, Widdowson E. 2002. McCance and Widdowson's the Composition of Foods, 6th Edition ed. Royal Society of Chemistry: Cambridge.

McCance RA, Widdowson E. 2014. McCance and Widdowson's the Composition of Foods, 7th Edition ed. Royal society of chemistry: Cambridge. 
Moyersoen I, Devleesschauwer B, Dekkers A, Verkaik-Kloosterman J, De Ridder K, Vandevijvere S, Tafforeau J, Van Oyen H, Lachat C, Van Camp J. 2019. A Novel Approach to Optimize Vitamin D Intake in Belgium through Fortification Based on Representative Food Consumption Data. J Nutr. 149:1852-1862.

Pojednic RM, Ceglia L. 2014. The Emerging Biomolecular Role of Vitamin D in Skeletal Muscle. Exerc Sport Sci Rev. 42:76-81.

Public Health England and Food Standards Agency. 2014. National Diet and Nutrition Survey Results from Years 1, 2, 3 and 4 (Combined) of the Rolling Programme (2008/2009 - 2011/2012).

Raulio S, Erlund I, Männistö S, Sarlio-Lähteenkorva S, Sundvall J, Tapanainen H, Vartiainen E, Virtanen SM. 2017. Successful nutrition policy: improvement of vitamin D intake and status in Finnish adults over the last decade. Eur J Pub Health. 27:268-273.

Scientific Advisory Committee on Nutrition (SACN). 2016. SACN Vitamin D and Health Report.

Sweeney J. 2016. Regional Weather and Climates of the British Isles - Part 6: Ireland. Weather. 69:20-27.

Thacher TD, Clarke BL. 2011. Vitamin D Insufficiency. Mayo Clin Proc. 86:50-60.

Todd JJ, Pourshahidi LK, McSorley EM, Madigan SM, Magee PJ. 2015. Vitamin D: Recent Advances and Implications for Athletes. Sports Med. 45:213-229.

Trenerry VC, Plozza T, Caridi D, Murphy S. 2011. The Determination of Vitamin $\mathrm{D}_{3}$ in Bovine Milk by Liquid Chromatography Mass Spectrometry. Food Chem. 125:1314-1319.

UK Data Service. 2014. National Diet and Nutrition Survey Years 1-4, 2008/09-2011/12.

Webb AR, Holick MF. 1988. The Role of Sunlight in the Cutaneous Production of Vitamin $\mathrm{D}_{3}$. Ann Rev Nutr. 8:375-399.

Webb AR, Kline L, Holick MF. 1988. Influence of Season and Latitude on the Cutaneous Synthesis of Vitamin $D_{3}$ : Exposure to Winter Sunlight in Boston and Edmonton Will Not Promote Vitamin $\mathrm{D}_{3}$ Synthesis in Human Skin. J Clin Endocrinol Metab. 67:373-378.

Weir RR, Strain JJ, Johnston M, Lowis C, Fearon AM, Stewart S, Pourshahidi LK. 2017. Environmental and Genetic Factors Influence the Vitamin D Content of Cows' Milk. Proc Nutr Soc. 76:76-82.

Willet W. 2013. Nutritional Epidemiology, 3rd Edition ed. Oxford Press: New York, NY. 


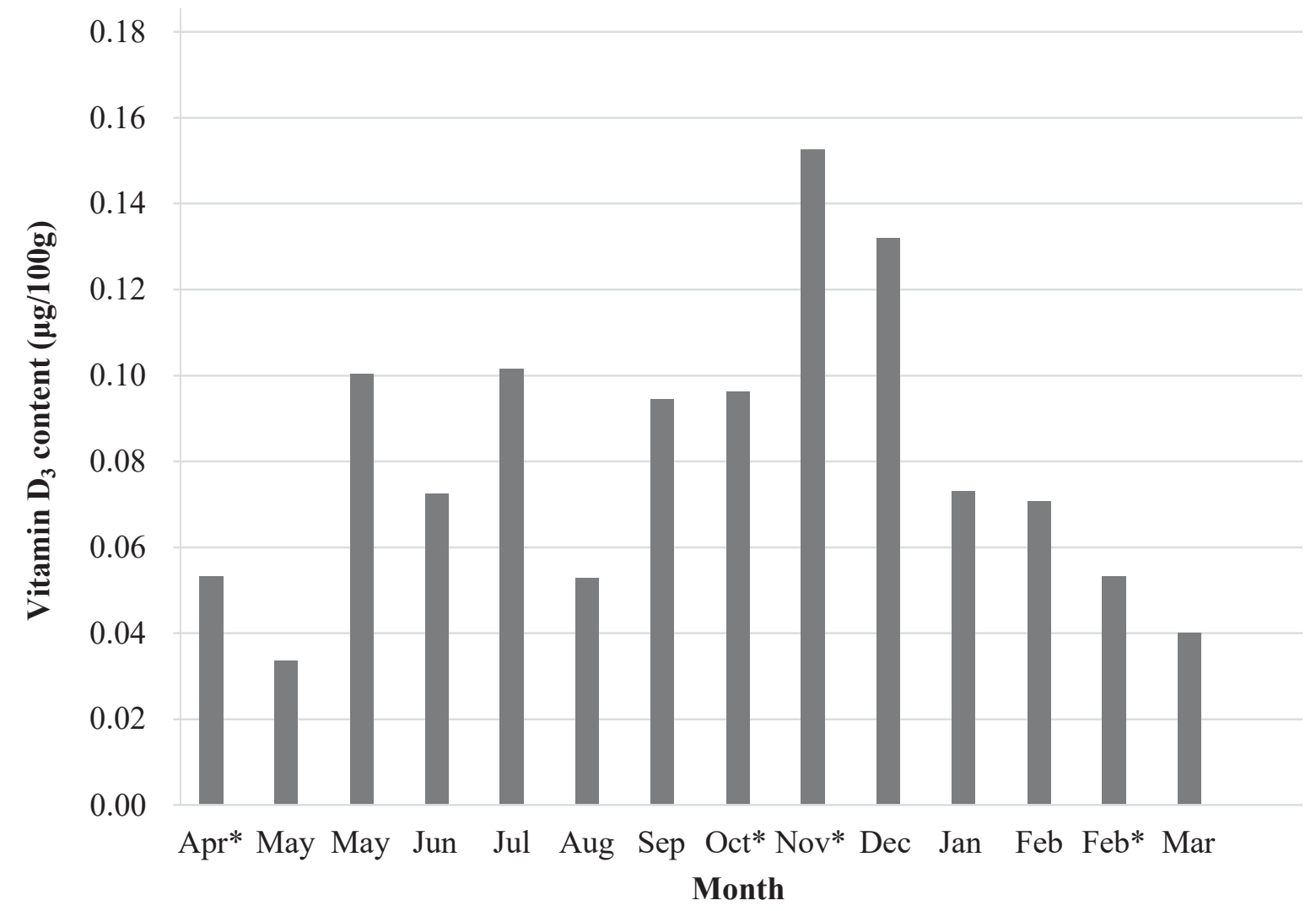

Fig. 1. Vitamin $D_{3}$ content $(\mu \mathrm{g} / 100 \mathrm{~g})$ of raw milk produced in Northern Ireland over a year period. Bars show mean vitamin $\mathrm{D}_{3}$ of samples collected from two processors across Northern Ireland. *Results available from one processor only. 


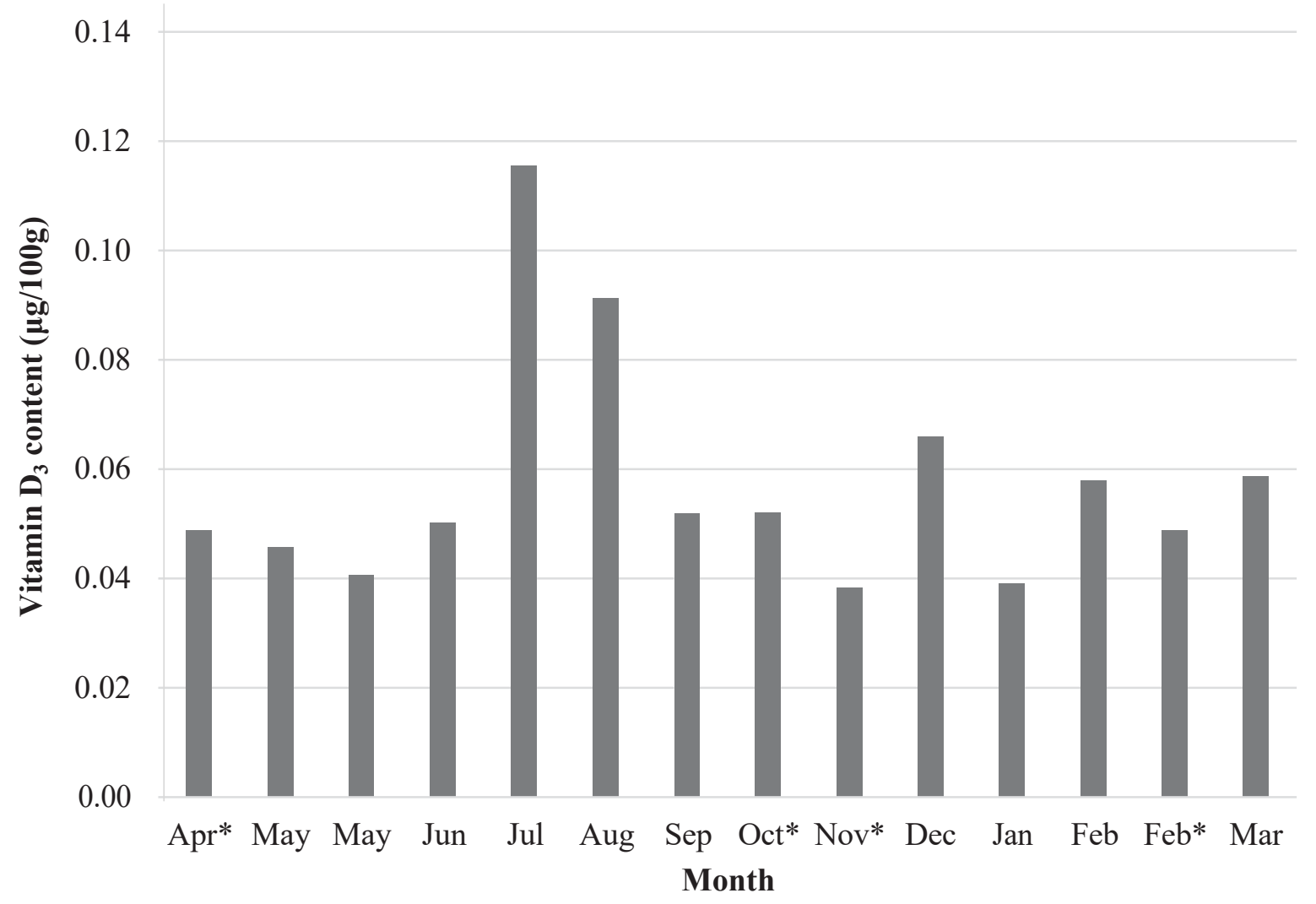

Fig. 2. Vitamin $D_{3}$ content $(\mu \mathrm{g} / 100 \mathrm{~g})$ of pasteurised whole milk produced in Northern Ireland over a year period. Bars show mean vitamin $\mathrm{D}_{3}$ of samples collected from two processors across Northern Ireland. *Results available from one processor only. 


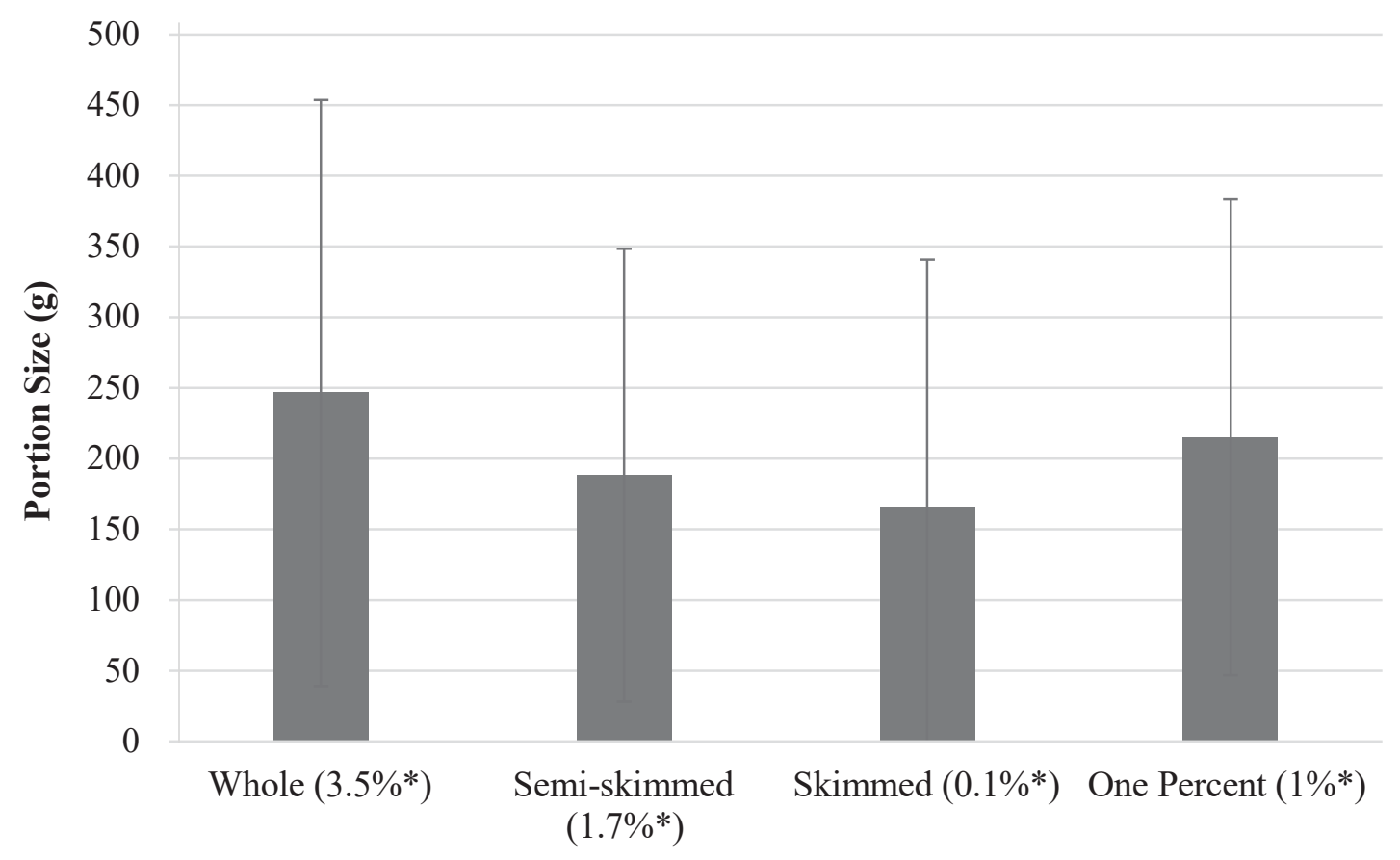

Milk Type

Fig. 3. Mean portion size (g) of milk consumed by participants $(n 4,156)$ per eating occasion for each milk type. *Typical fat content of each milk type. 


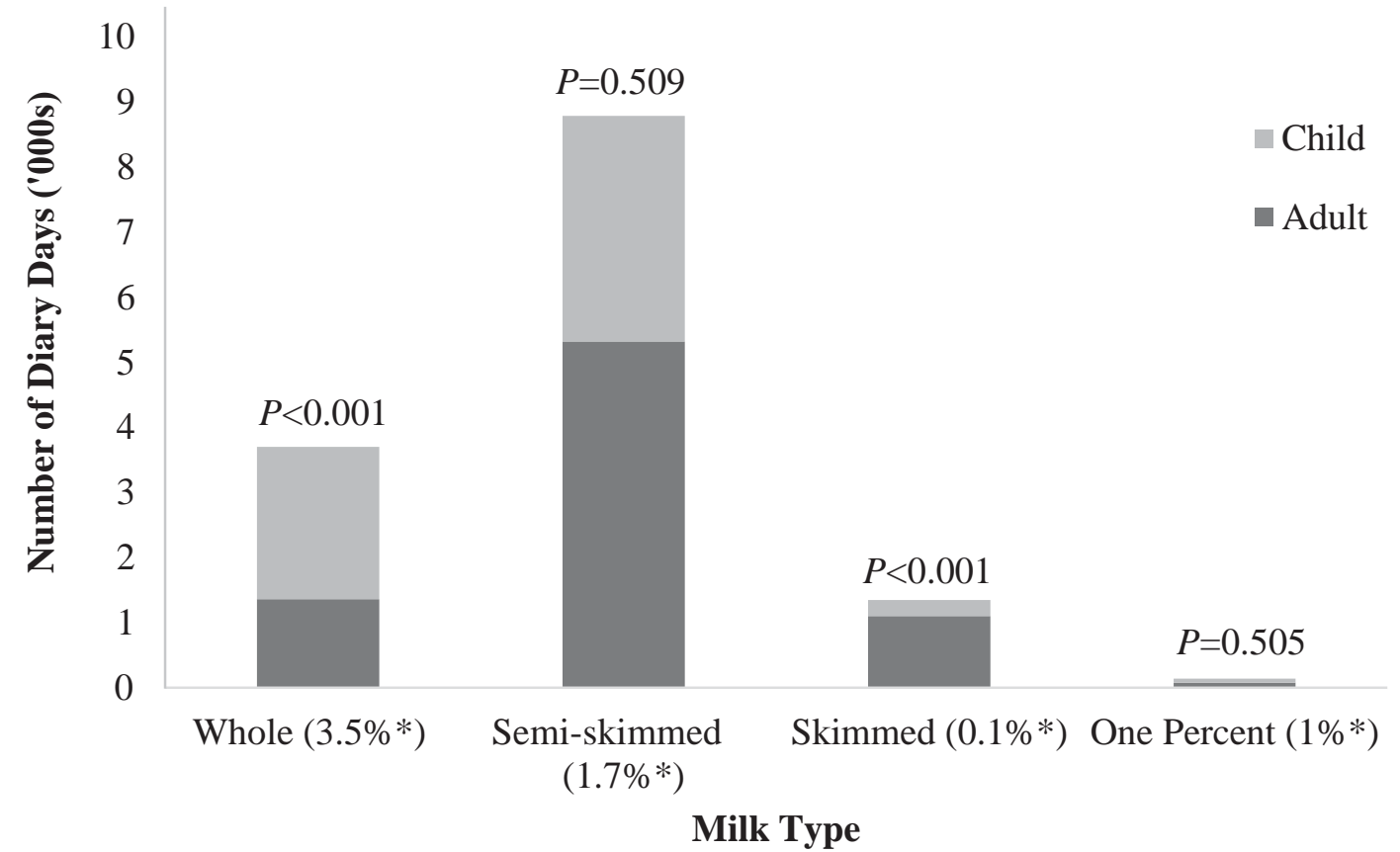

Fig. 4. Frequency of consumption of each milk type by adults (18-94 years; dark bars $n$ 2,174) and children (1.5-17 years; light bars, $n$ 1,982). *Refers to average fat content of each milk type. $P$-values indicate a significant difference between the number of diary days each type of milk was consumed between adults and children $(P<0.05)$. 
Table 1: National Diet and Nutrition Survey (NDNS) population data (Public Health England, 2014)

\begin{tabular}{|c|c|c|c|}
\hline \multirow[b]{2}{*}{ Age (yrs) } & \multicolumn{3}{|c|}{ Sample size $(n 4,156)$} \\
\hline & Male & Female & Total \\
\hline $1.5-3$ & 207 & 179 & 386 \\
\hline $4-10$ & 414 & 389 & 803 \\
\hline $11-15$ & 278 & 265 & 543 \\
\hline $16-18$ & 167 & 174 & 341 \\
\hline $19-49$ & 471 & 640 & 1111 \\
\hline $50-64$ & 239 & 305 & 544 \\
\hline$\geq 65$ & 191 & 237 & 428 \\
\hline Total & 1967 & 2189 & 4156 \\
\hline
\end{tabular}

Table prepared using the demographic information provided in the NDNS report (2014) 
Table 2: Theoretical impact vitamin D fortification of milk on vitamin D intakes of the population based on the NDNS data $(n 4,156)$

\begin{tabular}{|c|c|c|c|c|c|c|}
\hline \multirow[b]{3}{*}{ Vitamin D concentration } & \multicolumn{6}{|c|}{ Total Population } \\
\hline & \multicolumn{4}{|c|}{ Vitamin D intake ( $\mu \mathrm{g} /$ day) } & \multicolumn{2}{|c|}{ Population percentage $(\%)$} \\
\hline & Mean $\pm \mathrm{SD}$ & Median & Minimum & Maximum & Meeting $\mathrm{RNI}^{\dagger}$ & Exceeding $\mathrm{UL}^{\ddagger}$ \\
\hline No fortification* & $2.50 \pm 1.87$ & 2.03 & 0.00 & 20.96 & 0.89 & 0 \\
\hline $1 \mu \mathrm{g} / 100 \mathrm{~g}$ & $4.20 \pm 2.48$ & 3.69 & 0.02 & 23.94 & 2.96 & 0 \\
\hline $1.5 \mu \mathrm{g} / 100 \mathrm{~g}$ & $5.06 \pm 3.08$ & 4.42 & 0.02 & 33.98 & 6.88 & 0 \\
\hline $2 \mu \mathrm{g} / 100 \mathrm{~g}$ & $5.91 \pm 3.77$ & 5.11 & 0.02 & 44.01 & 12.29 & 0 \\
\hline
\end{tabular}

NDNS, National Diet and Nutrition Survey, dataset available from the UK Data Archives (2014)

${ }^{\dagger}$ RNI, Reference Nutrient Intake (or safe intake) for vitamin D of $10 \mu \mathrm{g} /$ day for those aged $>1$ year (SACN 2016)

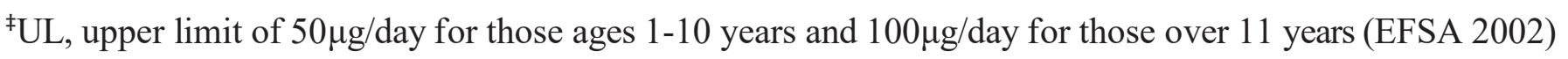

*Vitamin D content of milk as listed in the McCance and Widdowson (2002) 
Table 3: Theoretical impact of vitamin D fortification of milk on vitamin D intakes of those individuals deemed to be at risk of vitamin

D deficiency (COMA 1991) based on the NDNS data

\begin{tabular}{|c|c|c|c|c|c|c|c|c|c|c|c|c|}
\hline \multirow[b]{3}{*}{$\begin{array}{l}\text { Vitamin D } \\
\text { concentration }\end{array}$} & \multicolumn{4}{|c|}{ Children aged $1-3$ years $(n 386)$} & \multicolumn{4}{|c|}{ Women of childbearing age ( $n$ 814) } & \multicolumn{4}{|c|}{ Adults aged over 65 years $(n 428)$} \\
\hline & \multicolumn{2}{|c|}{$\begin{array}{c}\text { Vitamin D intake } \\
(\mu \mathrm{g} / \text { day })\end{array}$} & \multicolumn{2}{|c|}{$\begin{array}{c}\text { Population } \\
\text { percentage (\%) }\end{array}$} & \multicolumn{2}{|c|}{$\begin{array}{c}\text { Vitamin D intake } \\
(\mu \mathrm{g} / \mathrm{day})\end{array}$} & \multicolumn{2}{|c|}{$\begin{array}{c}\text { Population } \\
\text { percentage (\%) }\end{array}$} & \multicolumn{2}{|c|}{$\begin{array}{c}\text { Vitamin D intake } \\
(\mu \mathrm{g} / \text { day })\end{array}$} & \multicolumn{2}{|c|}{$\begin{array}{c}\text { Population } \\
\text { percentage (\%) }\end{array}$} \\
\hline & $\begin{array}{c}\text { Mean } \pm \\
\text { SD }\end{array}$ & Median & $\begin{array}{c}\text { Meeting } \\
\mathrm{RNI}^{\dagger}\end{array}$ & $\begin{array}{c}\text { Exceeding } \\
\mathrm{UL}^{\ddagger}\end{array}$ & $\begin{array}{c}\text { Mean } \pm \\
\text { SD }\end{array}$ & Median & $\begin{array}{c}\text { Meeting } \\
\mathrm{RNI}^{\dagger}\end{array}$ & $\begin{array}{c}\text { Exceeding } \\
\mathrm{UL}^{\ddagger}\end{array}$ & $\begin{array}{c}\text { Mean } \pm \\
\text { SD }\end{array}$ & Median & $\begin{array}{c}\text { Meeting } \\
\mathrm{RNI}^{\dagger}\end{array}$ & $\begin{array}{c}\text { Exceeding } \\
\mathrm{UL}^{\ddagger}\end{array}$ \\
\hline No fortification* & $\begin{array}{r}1.96 \pm \\
2.05 \\
4.80 \pm\end{array}$ & 1.41 & 2.12 & 0 & $\begin{array}{r}2.28 \pm \\
1.65 \\
3.44 \pm\end{array}$ & 1.82 & 0.74 & 0 & $\begin{array}{r}3.40 \pm \\
2.39 \\
5.25 \pm\end{array}$ & 2.75 & 1.65 & 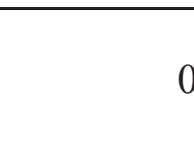 \\
\hline $1 \mu \mathrm{g} / 100 \mathrm{~g}$ & $\begin{array}{r}2.59 \\
6.21 \pm\end{array}$ & 4.42 & 4.15 & 0 & $\begin{array}{r}2.03 \\
4.01 \pm\end{array}$ & 2.99 & 1.60 & 0 & $\begin{array}{r}2.79 \\
6.18 \pm\end{array}$ & 4.69 & 6.07 & 0 \\
\hline $1.5 \mu \mathrm{g} / 100 \mathrm{~g}$ & $\begin{array}{r}3.42 \\
7.63 \pm\end{array}$ & 5.53 & 12.18 & 0 & $\begin{array}{r}2.39 \\
4.59 \pm\end{array}$ & 3.50 & 2.70 & 0 & $\begin{array}{r}3.20 \\
7.10 \pm\end{array}$ & 5.50 & 13.08 & 0 \\
\hline $2 \mu \mathrm{g} / 100 \mathrm{~g}$ & 4.39 & 6.87 & 25.65 & 0 & 2.80 & 3.99 & 5.04 & 0 & 3.70 & 6.40 & 17.76 & 0 \\
\hline
\end{tabular}

NDNS, National Diet and Nutrition Survey, dataset available from UK Data Archives (2014)

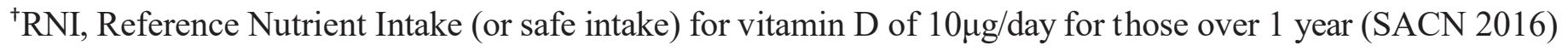

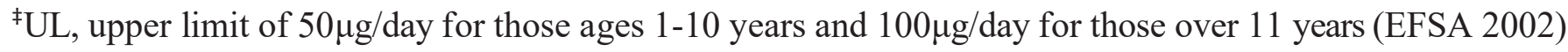

*Vitamin D content of milk as listed in the McCance and Widdowson (2002) 
Table 4: Theoretical impact of vitamin D fortification of milk on the dietary vitamin D intake of the population based on reported diary days $(n 16,539)$

\begin{tabular}{|c|c|c|c|c|c|c|c|c|}
\hline \multirow[b]{4}{*}{ Milk Type } & \multicolumn{8}{|c|}{ Total vitamin D intake ( $\mu \mathrm{g} /$ day $)$} \\
\hline & \multicolumn{8}{|c|}{ Fortification of milk } \\
\hline & \multicolumn{2}{|c|}{ Not Fortified* } & \multicolumn{2}{|c|}{$1 \mu \mathrm{g} / 100 \mathrm{~g}$} & \multicolumn{2}{|c|}{$1.5 \mu \mathrm{g} / 100 \mathrm{~g}$} & \multicolumn{2}{|c|}{$2 \mu \mathrm{g} / 100 \mathrm{~g}$} \\
\hline & Median & Percentiles & Median & Percentiles & Median & Percentiles & Median & Percentiles \\
\hline Whole & $2.0^{\mathrm{a}}$ & $1.0-3.6$ & $4.9^{\mathrm{b}}$ & $3.1-.7 .3$ & $6.2^{\mathrm{c}}$ & $3.9-9.2$ & $7.4^{\mathrm{d}}$ & $4.5-11.2$ \\
\hline Semi-skimmed & $2.3^{\mathrm{a}}$ & $1.2-4.0$ & $4.3^{\mathrm{b}}$ & 2.9-6.6 & $5.3^{\mathrm{c}}$ & $3.5-8.1$ & $6.1^{\mathrm{d}}$ & $4.0-9.5$ \\
\hline Skimmed & $2.6^{\mathrm{a}}$ & $1.2-5.1$ & $4.2^{\mathrm{b}}$ & $2.4-7.5$ & $5.2^{\mathrm{c}}$ & $2.9-8.5$ & $6.0^{\mathrm{d}}$ & $3.1-9.4$ \\
\hline One percent & $2.7^{\mathrm{a}}$ & $1.4-8.5$ & $4.6^{\mathrm{b}}$ & $2.8-9.0$ & $5.5^{\mathrm{c}}$ & $3.1-9.1$ & $6.5^{\mathrm{d}}$ & $3.8-9.2$ \\
\hline
\end{tabular}

Consumption of milk and baseline vitamin D intake as found in the National Diet and Nutrition Survey, dataset available from UK Data Archives (2014)

* Vitamin D content of milk as listed in the McCance and Widdowson (2002) Percentiles $\left(25^{\text {th }}-75^{\text {th }}\right)$

a,b,c,d Values within a row with different superscript letters are significantly different $(P<0.001$, Friedman Test and Wilcoxon Signed Rank test) 